\title{
The CAG Repeat within the Androgen Receptor Gene and Its Relationship to Cryptorchidism
}

\author{
M. Silva-Ramos, J. M. Oliveira, J. M. Cabeda, A. Reis, J. Soares, A. Pimenta \\ Department of Urology and Laboratory of Molecular Biology, Santo Antonio General Hospital, and \\ Department of Pediatric Urology, Maria Pia Children Hospital, Porto, Portugal
}

\begin{abstract}
Purpose: We examined the significance of the CAG repeat polymorphism in the pathogenesis of cryptorchidism. Materials and Methods: Genomic deoxyribonucleic acid (DNA) was extracted from blood samples from 42 cryptorchid boys and from 31 non-cryptorchid control subjects. In the cryptorchid group, 7 had bilateral cryptorchidism and 6 had patent processus vaginalis in the contralateral side. To determine the number of CAG repeats, the DNA was amplified by polymerase chain reaction and sequenced.

Results: The mean CAG repeat length in the AR gene was 22.5 (range 16 to 28) in patients and 21.5 (range 17 to 26) in controls (non-significant). Patients with bilateral cryptorchidism had a mean length of 24.3 (range 21 to 26 ) and patients with unilateral cryptorchidism and patent processus vaginalis in the contra lateral side had a mean of 25.2 (range 21 to 28), which was statistically different from controls $(\mathrm{p}=0.015$ and $\mathrm{p}=0.005$ respectively).

Conclusion: CAG repeat length of the AR gene does not seem to play a major role in patients with unilateral cryptorchidism. However, in patients with bilateral undescended testis, a less functional androgen receptor through a longer polyglutamine chain may have a role in its pathogenesis. In the same way, patients with unilateral cryptorchidism a contralateral patent processus vaginalis have longer CAG repeats that might be responsible for a slower testicular descent and incomplete closure of the processus vaginalis.
\end{abstract}

Key words: cryptorchidism; androgens receptors; genetic polymorphisms

Int Braz J Urol. 2006; 32: 330-5

\section{INTRODUCTION}

Cryptorchidism is the most common congenital genital abnormality. Although it may be associated with a number of chromosomal and hereditary disorders, the majority of cases are isolated and the exact etiology remains to be defined. One of the several factors important in testicular descent is the presence of androgens and functional androgen receptor. The critical role of the androgen receptor (AR) in the development of the external genitalia is evident in the various forms of the androgen insensitivity syndrome (1). Hutson suggested that androgens are important mainly on the inguinal portion of the testicular descent, because mice with the testicular feminization ( $\mathrm{Tfm})$ mutation that confers a complete androgen resistance phenotype had uniformly descended testis to the level of the internal inguinal ring, but no further (2).

The AR gene is located on the X chromosome, so in normal $46 \mathrm{XY}$ males, only one copy of the gene is present, and any alteration of the gene 
may result in an abnormality of phenotypic development. The AR gene consists of 8 exons. Exon 1 is the largest and encodes the transactivation domain, which determines the transcriptional activity of the receptor. Exons 2 and 3 encode the receptor DNA binding domain, and exons 5 to 8 encode the portion of the receptor that binds to androgens. Mutations in the DNA and ligand binding domains have been reported in various androgen resistance phenotypes (3-5), however these mutations were not found in patients with isolated undescended testis (6).

Exon 1 codes a highly polymorphic glutamine (CAG) repetitive sequence. In vitro studies have shown that the longer the polyglutamine repeat the lesser the transcriptional activity of the receptor $(7,8)$. There is evidence that this may be clinically important. Large expansions of the polyglutamine tract result in spinal bulbar atrophy, a fatal neuromuscular disease associated with low virilization and infertility, in these patients the severity of the disease is correlated with the repeat length (9). Also various studies showed an increased number of CAG repeats in patients with isolated infertility, and in XY males with undermasculinized genitalia (10-13). In the current study we analyzed the CAG repeat length in the AR gene in patients with cryptorchidism and no other genital abnormality.

\section{MATERIALS AND METHODS}

Forty-two patients were prospectively recruited for this study from the operative cases of 2 hospitals. The sole inclusion criterion was the presence of cryptorchidism with no other genital malformations. Patients with hernia and/or hydrocele were included, and patency of the processus vaginalis was accessed at surgery. They ranged in age from 3 to 77 years (mean 20.9). Seven had bilateral cryptorchidism, 6 had unilateral undescended testis with clinically evident patent processus vaginalis (PPV) in the contralateral side, 3 patients had unilateral ectopic testis in the superficial inguinal pouch and 2 had unilateral intrabdominal testis. Thirty-one volunteers with no personal or fam- ily history of genital abnormalities were recruited among the hospital staff to form a control group. They ranged in age from 22 to 69 years (mean 41.7). Informed consent was obtained from all subjects or from their parents under an approved protocol by the hospitals' Ethic Committees.

Genomic DNA was extracted from whole blood samples stored at $-20^{\circ} \mathrm{C}$, using the automated instrument MagNA Pure LC (Roche, Germany), with the MagNA Pure LC DNA Isolation Kit I (Roche, Germany), and the DNA I - Whole Blood/High Performance extraction method.

The CAG repeat region was amplified by polymerase chain reaction (PCR), using previously described primers (14) - sense (5')-AGAGGCC GCGAGCGCAGCACCTC-(3'), and antisense (5')GCTGTGAAGGTTGCTGTTCCTCAT-(3'). The PCR reactions were carried out with 100 ng DNA in a $50 \mu \mathrm{L}$ volume containing $5.0 \mu \mathrm{L}$ of $10 \mathrm{x} \mathrm{Mg} 2+-$ free buffer for DyNAzyme EXT DNA polymerase (Finnzymes, Finland), 1.0mM MgCl2, $0.2 \mathrm{mM}$ of each dNTP, 15 pmol of each primer, and $2.0 \mathrm{U}$ of DyNAzyme EXT DNA polymerase. The samples were subjected to denaturation at $95^{\circ} \mathrm{C}$ for 5 minutes, followed by 45 cycles of amplification consisting of denaturation at $95^{\circ} \mathrm{C}$ for 1 minute, annealing for 1 minute at $65^{\circ} \mathrm{C}$, and extension for 1 minute at $70^{\circ} \mathrm{C}$. A final extension step at $70^{\circ} \mathrm{C}$ for 5 minutes was also performed.

The amplified fragments were run on a $3.5 \%$ intermediate melting temperature agarose gel (MetaPhor agarose, BioWhittaker Molecular Applications, USA), in chilled 1x TBE for 7 hours and 30 minutes at $5.2 \mathrm{~V} / \mathrm{cm}$. The agarose gels were subsequently stained with GelStar nucleic acid gel stain (FMC BioProducts, USA), and visualized on the Fluor-S MultImager analyzer (BioRad). PCR fragment length was determined by comparison with a $10 \mathrm{bp}$ molecular weight ladder (Invitrogen, UK), and results were accepted if concordant in at least three experiments. Afterwards, for each group of samples with differing CAG number, one sample was sequenced (DNA Sequencing Kit - BigDye Terminator Cycle Sequencing v3.1, Applied Biosystems) on a ABI PRISM 310 instrument (Applied Biosystems) and used as a DNA CAG-repeat size standard. These stan- 
dards were compared to the non-sequenced samples by microchip electrophoresis (LabChip and DNA 500 Reagents, Agilent Technologies) on an Agilent 2100 Bioanalyzer (Agilent).

Data analysis was computer based using commercially available software. Because AR transcriptional activity decreases linearly across the entire CAG spectrum $(7,8)$, we analyzed CAG repeats as a continuous variable. Normal data distribution was assessed using the Kolmogorov-Smirnov test. Differences in CAG repeat length were tested by the independent samples $t$ test when data distribution was normal, and by Mann-Whitney test in the smaller subgroups with no normal distribution. Statistical significance was considered at $\mathrm{p}<0.05$.

\section{RESULTS}

The mean CAG repeat length was 22.5 (range 16 to 28 ) in patients and 21.5 (range 17 to 26 ) in controls $(\mathrm{p}=$ non-significant). Patients with bilateral cryptorchidism had a mean length of 24.3 (range 21 to 26) and patients with unilateral cryptorchidism and PPV in the contra lateral side had a mean of 25.2 (range 21 to 28). There was a statistically significant difference in the bilateral cryptorchid group and in the patent processus vaginalis group compared to controls ( $p=0.014$ and $p=0.019$ respectively) (Table1). Six patients had positive family history for cryptorchidism. These patients belonged to 2 families; in both families child, father and paternal grandfather were affected, and as expected there was no concor- dance in the number of CAG repeats between family members.

\section{COMMENTS}

Androgens clearly have a role in testicular descent (15), and a diminished androgenic stimulation may be responsible for a slower and incomplete testicular descent. Biologic and epidemiologic evidence suggests that moderate expansions of the CAG repeat, can influence androgen receptor activity and may be important in several clinical situations. Longer CAG repeats have been associated with several phenotypes of undermasculinized genitalia and idiopathic infertility. Lim et al. analyzing tissue samples from patients with abnormal male genital development, selected from the Cambridge intersex database found that patients with less severe malformations and unknown etiology tended to have longer CAG repeats compared to those with more severe malformations and known etiology (13). Suggesting that patients with less severe abnormalities have a multifactorial cause, and a small reduction of function of the AR could be important added to other "weak" causal factors in this group of patients. They also studied the CAG repeat length in groups of patients with different levels of testicular descent, and found no difference (13), however these groups were not compared to a population with no genital abnormality. Similarly Sasagawa et al. did not found a significant difference in the CAG repeat length between patients with cryptorchidism and controls in a Japanese population (16). Our data

Table 1 - Number of CAG repeats in the AR gene in cryptorchid and non-cryptorchid subjects.

\begin{tabular}{lccc}
\hline & Mean Length \pm SD (range) & Median Length & p Value $^{\mathrm{a}}$ \\
\hline Controls & $21.5 \pm 2.7(16-26)$ & 22 & \\
All cryptorchid patients & $22.4 \pm 3.2(15-29)$ & 22.5 & $0.206^{\mathrm{b}}$ \\
Unilateral cryptorchidism & $22.1 \pm 3.3(15-29)$ & 21 & $0.474^{\mathrm{b}}$ \\
Bilateral cryptorchidism & $24.7 \pm 1.8(21-26)$ & 25.5 & $0.019^{\mathrm{c}}$ \\
Unilateral cryptorchidism with & $25.2 \pm 2.9(20-29)$ & 25 & $0.014^{\mathrm{c}}$ \\
$\quad$ & & & \\
\hline
\end{tabular}

$a=$ comparing to controls; $b=$ student $t$ test $; c=$ Mann-Whitney test . 
however, suggests that a difference may exist in a subset of patients. Comparing to our study the most striking difference was noted in the higher mean number of repeats in the control group of the Japanese patients. In fact the number of CAG repeats in Asians seems to be higher than in Caucasians $(17,18)$, this could explain the higher incidence of Cryptorchidism in Asian populations (19) and perhaps in these populations the impact of this polymorphism in distinguishing patients from controls is minor.

A recent study (20) also showed that a combination of longer CAG repeats associated with longer GGC repeats in the AR gene, was more frequent in patients with bilateral cryptorchidism than on controls. In our series, patients with bilateral cryptorchidism and patients with unilateral cryptorchidism and contralateral PPV also had significant longer CAG repeats. Albeit the statically significance of the results, the short number of patients in these subgroups hinders definite conclusions. However is plausible that in these patients a less functional androgen receptor could be responsible for a slower testicular descent originating bilateral undescended testis or a unilateral undescended testis and a later testicular descent in the contralateral side resulting in an incomplete closure of the processus vaginalis.

Obliteration of the processus vaginalis normally occurs after testicular descent is complete (21), and spontaneous closure may occur in the first year of life, perhaps in response to the testosterone surge that occurs in the first months of postnatal life (22). Our data further supports a role for androgens in the closure of the processus vaginalis.

Androgen receptor gene alterations have been associated with partial or complete androgen insensitivity syndrome; a phenotype that often includes cryptorchidism, which is usually bilateral. Our data also shows that patients with bilateral undescended testes with no other genital abnormalities may also have a less functional androgen receptor through a longer polyglutamine chain. On the other hand unilateral cryptorchidism is often isolated, and not associated with AR gene mutations (6) or longer CAG repeats. This supports the idea that unilateral and bilateral cryptorchidism has different pathogenesis, and that bilateral cryptorchidism is more likely to have a genetic basis and an endocrine cause.

\section{CONFLICT OF INTEREST AND FINANCIAL SUPPORT}

This project was supported by an educational grant from the Portuguese Urological Association and Abbott Laboratories.

\section{REFERENCES}

1. Wiener JS, Teague JL, Roth DR, Gonzales ET Jr, Lamb DJ: Molecular biology and function of the androgen receptor in genital development. J Urol. 1997; 157: 1377-86.

2. Hutson JM: Testicular feminization: a model for testicular descent in mice and men. J Pediatr Surg. 1986; 21: 195-8.

3. McPhaul MJ, Marcelli M, Zoppi S, Wilson CM, Griffin JE, Wilson JD: Mutations in the ligand-binding domain of the androgen receptor gene cluster in two regions of the gene. J Clin Invest. 1992; 90: 2097-101.

4. McPhaul MJ, Marcelli M, Zoppi S, Griffin JE, Wilson JD: Genetic basis of endocrine disease. 4. The spectrum of mutations in the androgen receptor gene that causes androgen resistance. J Clin Endocrinol Metab. 1993; 76: 17-23.

5. Zoppi S, Marcelli JP, Griffin JE, Deslypere JP, Wilson JD, McPhaul MJ: Amino acid substitutions in the DNAbinding domain of the human androgen receptor are a frequent cause of receptor binding positive androgen resistance. Mol Endocrinol 1992; 6: 409-15.

6. Wiener JS, Marcelli M, Gonzales ET Jr, Roth DR, Lamb DJ: Androgen receptor gene alterations are not associated with isolated cryptorchidism. J Urol. 1998; 160: 863-5.

7. Chamberlain NL, Driver ED, Miesfeld RL: The length and location of CAG trinucleotide repeats in the androgen receptor $\mathrm{N}$-terminal domain affect transactivation function. Nucleic Acids Res. 1994; 22 : 3181-6.

8. Kazemi-Esfarjani P, Trifiro MA, Pinsky L: Evidence for a repressive function of the long polyglutamine tract in the human androgen receptor: possible pathogenetic relevance for the (CAG)n-expanded neuronopathies. Hum Mol Genet. 1995; 4: 523-7. 
9. La Spada AR, Roling DB, Harding AE, Warner CL, Spiegel R, Hausmanowa-Petrusewicz I, et al.: Meiotic stability and genotype-phenotype correlation of the trinucleotide repeat in X-linked spinal and bulbar muscular atrophy. Nat Genet. 1992; 2: 301-4.

10. Casella R, Maduro MR, Misfud A, Lipshultz LI, Yong EL, Lamb DJ: Androgen receptor gene polyglutamine length is associated with testicular histology in infertile patients. J Urol. 2003; 169: 224-7.

11. Tut TG, Ghadessy FJ, Trifiro MA, Pinsky L, Yong EL: Long polyglutamine tracts in the androgen receptor are associated with reduced trans-activation, impaired sperm production, and male infertility. J Clin Endocrinol Metab. 1997; 82: 3777-82.

12. Lim HN, Chen H, McBride S, Dunning AM, Nixon RM, Hughes IA, et al.: Longer polyglutamine tracts in the androgen receptor are associated with moderate to severe undermasculinized genitalia in XY males. Hum Mol Genet. 2000; 9: 829-34.

13. Lim HN, Nixon RM, Chen H, Hughes IA, Hawkins JR: Evidence that longer androgen receptor polyglutamine repeats are a causal factor for genital abnormalities. J Clin Endocrinol Metab. 2001; 86: 3207-10.

14. Bousema JT, Bussemakers MJ, van Houwelingen KP, Debruyne FM, Verbeek AL, de La Rosette JJ, et al.: Polymorphisms in the vitamin $\mathrm{D}$ receptor gene and the androgen receptor gene and the risk of benign prostatic hyperplasia. Eur Urol. 2000; 37: 2348.
15. Husmann DA, Levy JB: Current concepts in the pathophysiology of testicular undescent. Urology. 1995; 46: 267-76.

16. Sasagawa I, Suzuki Y, Tateno T, Nakada T, Muroya K, Ogata T: CAG repeat length of the androgen receptor gene in Japanese males with cryptorchidism. Mol Hum Reprod. 2000; 6: 973-5.

17. Edwards A, Hammond HA, Jin L, Caskey CT, Chakraborty R: Genetic variation at five trimeric and tetrameric tandem repeat loci in four human population groups. Genomics. 1992; 12: 241-53.

18. Hsing AW, Gao YT, Wu G, Wang X, Deng J, Chen YL, et al.: Polymorphic CAG and GGN repeat lengths in the androgen receptor gene and prostate cancer risk: a population-based case-control study in China. Cancer Res. 2000; 60: 5111-6.

19. Berkowitz GS, Lapinski RH: Risk factors for cryptorchidism: a nested case-control study. Paediatr Perinat Epidemiol. 1996; 10: 39-51.

20. Ferlin A, Garolla A, Bettella A, Bartoloni L, Vinanzi $\mathrm{C}$, Roverato A, et al.: Androgen receptor gene CAG and GGC repeat lengths in cryptorchidism. Eur J Endocrinol. 2005; 152: 419-25.

21. Barthold JS, Redman JF: Association of epididymal anomalies with patent processus vaginalis in hernia, hydrocele and cryptorchidism. J Urol. 1996; 156: 2054-6.

22. Hadziselimovic F, Thommen L, Girard J, Herzog B: The significance of postnatal gonadotropin surge for testicular development in normal and cryptorchid testes. J Urol. 1986; 136: 274-6.

Correspondence address:

Dr. Miguel Silva-Ramos

Serviço de Urologia

Hospital Geral de Santo Antonio

Largo Prof. Abel Salazar, 4050

Porto, Portugal

Fax: + 3512 2203-0411

E-mail: miguel.silva_ramos@sapo.pt 


\section{EDITORIAL COMMENT}

A unilateral undescended testis is the most frequent form of cryptorchidism, There are, however, three different types of cryptorchidism: 1) primary, undescended testis(es) - UDT (common) since birth, 2) secondary, UDT descended at birth but subsequently ascends (in nearly $20 \%$ of all UDT) and, 3) UDT associated with a congenital syndrome ( $<1 \%$ all UDT). Furthermore, a considerable number of unilateral UDT with a retractile contra lateral testis will eventually progress to bilateral UDT.

In the present paper, Silva-Ramos et al. examined a small number of patients with bilateral UDT. It is therefore possible that this group of patients was skewed towards the congenital syndrome type of cryptorchidism. Moreover, the importance of open processus vaginalis is still a contentious issue today. On one side of the argument, an open processus vaginalis is frequently observed during autopsies in adult males with normal genitalia. On the other hand, cryptorchid boys with open processus vaginalis and epididymo-testicular dissociation have the lowest germ cell number and the most pronounced form of hypogonadotropic hypogonadism (1). If there is a defect of androgen receptors in those with bilateral UDT, then prepubertal hypergonadotropic hypogonadism must follow. This however does not correlate with previously published findings (1). Nevertheless, this paper contributes towards a better understanding of the role of androgens in epididymotesticular descent. Additional studies that include a larger number of patients with bilateral UDT are required in order to establish the necessity and the role of CAG-repeat for epididymo-testicular descent.

\section{REFERENCE}

1. Hadziselimovic F, Herzog B: Hodenerkrankungen im Kindesalter. Sttutgart, Hyppokrates Verlag, 1990.

Dr. Faruk Hadziselimovic
Kindertagesklinik Liestal
Liestal, Switzerland
E-mail: faruk@magnet.ch 